\author{
Мина М. ЂУРИЋ* \\ Филолошки факултет \\ Универзитет у Београду
}

Оригинални научни рад

Примљен: 11. 03. 2020.

Прихваћен: 15. 07. 2020.

\title{
КАТАЛОГЕНЕЗА КЊИГА У (ПОСТ)МОДЕРНОЈ ПРОЗИ
}

\begin{abstract}
У контексту одабраних примера из српске и светске књижевности, у раду се истражују и тумаче различити аспекти који се у доменима испитивања лексикографско-енциклопедијске парадигме тичу каталогенезе књига у (пост)модерној прози. Слеђењем, с једне стране, виђења да је навођење каталога књига у тексту и својеврсни „предах у приповедању” (Пекић 2002: 188), а, с друге стране, и идеје да се ,[...] расплет [...] романа [...] налази у регистру" (Павић 1996а: 405), у раду се анализира поетика каталога књига и његова функција у оквиру фукоовски представљене фантастичности библиотеке (Foucault 1967: 7-30).

Кључне речи: каталог књига, каталогенеза, (пост)модерна проза, српска и светска књижевност, преводи.
\end{abstract}

Према етимологији, речима каталог и каталогизирати (katalogos, katalegein) обухватају се и значења бројања, прибирања, али и читања и причања као својеврсног одабира и умножавања (уп. Senn 1996: 31-32). Када се облик оваквог значења јави у контексту Телемахових или Одисејевих причања, подразумева се да хомерско излагање, уколико претендује да представи све од истине и живота, обично укључује и неки каталог, односно набрајање (Хомер 2002a; Senn 1996: 32-33). Тако се, на пример, како је изражено и у сто шездесет деветом стиху првог певања Одисеје, при итачком сусрету Телемаха и Атене у обличју странца, од непознатог очекује да пот-

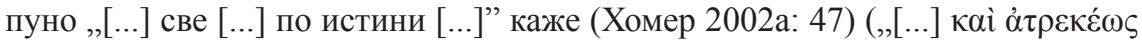

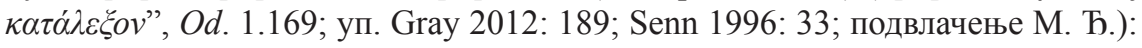
„Него нудер ми казуј и све ми по истини реци: | Ко си? Окле си? Где ти је дом? Где отац и мајка? | Каквим си стигао бродом! И како су с тобом бродари | дошли на Итаку амо? И којим се коленом диче?” (Хомер 2002a: 47). Уз изражену унутаркаталошку ритмичку динамизацију, и најдуже каталошке екфразе од неколико стотина стихова, какав је, на пример, каталог „ахејске војске”

*mina.m.djuric@gmail.com 
у Илијади, нераскидив су сижејни део хомерског текста (уп. Хомер 2002б: 82-90; Senn 1996: 33), што је према начину инкорпорирања каталога у оквиру епског певања погодно и за компаративна проматрања у контексту чувених каталога из српске усмене књижевности (уп. Златковић 1997: 117-126; Матицки 1997: 109-116; Сувајџић 2010: 91-109; Самарџија 2013: 25-38), као и за разноврсне интердисциплинарне приступе у оквирима анализа аксиолошке и онтолошке концепције бескрајних спискова (Eko 2011) и др.

Ипак, како се типологија каталога мења и у односу на доминирајућу поетичку парадигму, извесна разлика у начинима инкорпорирања каталошког набрајања, ${ }^{1}$ а посебно повећања одређене несижејности у контексту делокруга приказаног каталога (Lotman 1976: 308; Bošković 2004: 86), могла би да се уочи у сегментима у којима се каталогом, у неком смислу речи, наговештава и други тип медијалности, што упућује и на могућност постепеног издвајања таквог каталога у оквиру текста. Према разматраним примерима из одабраних књижевних дела, запажа се да се у односу на повећање несижејних карактеристика каталога (Lotman 1976: 308; Bošković 2004: 86) његово евидентније издвајање постиже на више различитих начина. Својеврсна кулминација кодне елидираности чинилаца у каталогу, као одраз и неког облика независности или пак суштинске немогућности сједињавања укључених актера, примећује се при крају „Киклопа”, дванаесте епизоде Џојсовог Уликса, где је у једном од интерполираних одељака понуђен каталог елидираних титула представника разних звања који, услед природне непогоде која се догодила, треба да се удруже у ,[r] $\mathrm{ad}[\mathrm{u}]$ na spasavanju, uklanjanju ruševina, posmrtnih ostataka [...]" (Džojs 2008: 362), о чему се у тексту сведочи имитацијом ефеката сниженог извештавалачког тона:

„The work of salvage, removal of debris, human remains etc has been entrusted to Messrs Michael Meade and Son, 159 Great Brunswick street, and Messrs T. and C. Martin, 77, 78, 79 and 80 North Wall, assisted by the men and officers of the Duke of Cornwall's light infantry under the general supervision of H. R. H., rear admiral, the right honourable sir Hercules Hannibal Habeas Corpus Anderson, K. G., K. P., K. T., P. C., K. C. B., M. P., J. P., M. B., D. S. O., S. O. D., M. F. H., M. R. I. A., B. L., Mus. Doc., P. L. G., F. T. C. D., F. R. U. I., F. R. C. P. I. and F. R. C. S. I." (U 12.1889-1896; подвлачење М. Ђ.). ${ }^{2}$

\footnotetext{
${ }^{1} \mathrm{O}$ значају литерарне традиције набрајања као једног од основних елемената каталогенезе сведочи и Кишово позивање на Борхеса у одломку есеја „Теме и варијације (из Складишта)”, насталом 1978. године: "'Nabrajanje je jedno od najstarijih pesničkih prosedea - setite se samo Psalama iz Svetog Pisma, prvog hora iz Persijanaca i kataloga lađa kod Homera - a osnovna zasluga enumeracije nije dužina, nego tanani spoj glagola, simpatija i neslaganje rečî.' (Borhes)" (Бopxec y Kiš 1983a: 25).

2 У преводу Зорана Пауновића тај одломак гласи: „Rad na spasavanju, uklanjanju ruševina, posmrtnih ostataka itd., poveren je gospodi Majklu Midu i sinu, ulica Grejt Bransvik 59, i gospodi T. i C. Martinu, Nort Vol 77, 78, 79 i 80, potpomognutim ljudstvom i oficirima lake pešadije vojvode od Kornvola pod vrhovnim zapovedništvom Nj. K. V, kontraadmirala, čestitog ser Herkulesa Hanibala Habeas Korpus Andersona V. P, V. S. P, V. T, K. S, V. Z. B, C. P, M. S, Dr. Med, O. Z, S. O. D, Z. P. L, Č. K. I. A, Dipl. Prav, Dr. Muz, Č. Z. S, Č. T. K. D, Č. K. U. I, Č. K. K. L. I, i Č. K. K. H. I" (Džojs 2008: 362-363). Уз превод, кроз додате коментаре тумачи се и значење наведених елизија: „Sve skraćenice (osim jedne) na kraju pasusa odnose se na stvarne titule, zvanja i udruženja. [...] Značenje skraćenica: vitez reda podvezice, vitez reda Svetog Patrika, vitez templar, vitez zapovednik Bata, član parlamenta, mirovni sudija, doktor medicine, nosilac ordena za zasluge, S. O. D. (engl. sod - tikvan, budala), zapovednik pasa lisičara, član Kraljevske irske akademije, diplomirani pravnik, doktor muzi-
} 
Каталошка енумерација титула као херменеутички знак заменљивости појединца и нехуманости ознака без смисаоне посебности и значаја, нарочито у приказаној ситуацији у овој епизоди Џојсовог Уликса, где би се у ствари очекивала другачија реакција претпостављених положаја, доноси саркастичан тон пародирајућег гласа и изразит утисак гротескности акумулације у претежности „другог” медијума унутар текста (уп. Džojs 2008: 362-363; Perišić 2013: 197).

Код аутора српске књижевности којима је поетички близак енциклопедизам каталошких генеза, ${ }^{3}$ примећује се и како ванкаталошки наратив не издржава динамику и темпо каталогизованог набрајања (уп. Петровић 2014: 173-174). У једном од примера из романа Дан шести Растка Петровића сума онога што представља каталог дата је у парентези, као својеврсна иконична представа „упакованог” простора ратног пртљага Стевана Папа-Катића:

„Стеван је одабирао шта ће даље носити од онога што му припада. (Три кошуље, троје гаће, шест џепних марамица, две поткошуље, двоје вунене чакшире, три пара вунених чарапа, два убруса, две салвете, једно ћебе, две школске књиге, једна књига шаховских задатака, два килограма печеног хлеба, килограм сланине, пола килограма кајмака, килограм шећера, пакет чаја, пола литра ракије. Све укупно око двадесет килограма.)" (Петровић 2014: 173-174).

Док би претходни пример из романа Дан шести Растка Петровића могао да се чита и као експликација (тока) свести текста о нужној (не)сижејној издвојености списка (уп. Петровић 2014: 173-174; Lotman 1976: 308; Bošković 2004: 86), још потпунија сижејна самосвојност таквог пописивања у односу и на друге, такође аутономне сегменте (кон)текста примећује се у виду интерполираних, вишеструких уметака ван свих обележја довршивог, које кроз рефлексије различитих околности историје и друштва поседују и сегменти биланса породице Његован, како је то приказано и у другом тому Пекићевог Златног руна, при Стефановом прегледу „[v]rednost[i] spoljnotrgovinske razmene Kneževine i Kraljevine Srbije od 1870. do 1900. izražen[e] u dinarima" (Pekić 2012: 358):

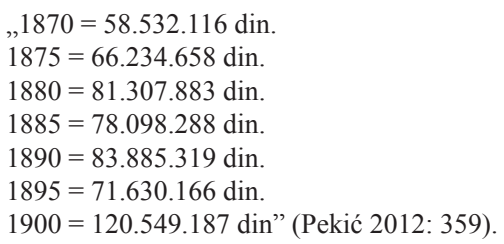

Ако би кроз претходно наведене примере могло да се закључи да се у односу на тип каталошког набрајања и доминирајућу поетичку парадигму принцип уланчавања каталога у оквиру текста мења, поставља се питање

ke, čuvar zakona o sirotinji, član Triniti koledža u Dablinu, član Kraljevskog univerziteta Irske, član Kraljevskog koledža lekara Irske, član Kraljevskog koledža hirurga Irske” (Пауновић у Džojs 2008: 362-363). О интерпретацијама овог и других Џојсових каталога из перспективе „smehovnog i komičkog čitanja” в. Perišić 2013: 197.

3 За истраживање енциклопедијске парадигме у романима Растка Петровића в. Петровић 2013. 
какво значење у доменима приказаних разлика задобија и потенцијално инкорпорирање каталога књига у делима српске и светске књижевности.

Један од најчувенијих каталога књига из историје светске књижевности свакако је и онај из седмог поглавља Раблеовог Пантагруела (Rabelais 1965: 37 и даље), где на различите начине имагинарно преслојен списак књига представља и својеврстан коментар и ревизију литерарне библиографије корпуса пређашњих изучавања (уп. Screech 1979: 60 и даље; Bodemer 2012: 4-17). Досадашња истраживања овог списка истицала су и изузетно Раблеово поверење у инкорпориране моћи каталога да се и извесним алузијама кроз наслове укаже на одређене проблематизоване аспекте догматских приступа разноврсним областима друштва, али се сатирична нота каталога књига анализирала и као превреднујућа у односу на основна начела каталогенезе, ${ }^{4}$ међу којима су и могућности повезивања елемената према предметном каталошком устројству и/или према алфабетном поретку (уп. Taylor 1961: 3; Screech 1979: 61; Besson 1980: 8 и даље; Bodemer 2012: 4-17). Типологија раблезијанског превазилажења систематизације коју нуди алфабет, као тек привид суштински (не)могуће структуре, своје упориште налази и у каснијим пародијско-полемичким дијалозима са узусима парадигме која се мења, што се показује и у Џојсовом Финегановом бдењу ( $F W$ 140.8-141.7). Кроз више питања и одговора својеврсног истражног поступка иронично се превреднује могућност систематски организованог излагања (под „a)”, „b)”, „c)”, „d)”), које чак ни поредак алфабетизације не може да обезбеди, па се тако на четврто питање као последњи одговор налази онај под „abcd)” (FW 140.8-141.7). Чак и летимичан поглед на раблезијанску хибридност овакве каталошке структуре не само што показује елементе постмодернистичке енциклопедичности (в. Senn 1996: 76) већ истовремено подразумева и рефлексију њене деконструкције. У том контексту би могло и да се закључи о природи освешћености изабраног текста који и каталогенезом (књига) постепено детронизује једну и условљава нову поетичку парадигму.

Питање да ли се каталози књига заступљени у тексту преводе представља изузетно важан поетички избор и отвара пространи полемички дијалог за тумачења. То показују и преводи почетног примера из поменутог Раблеовог списка, којим се актуелизује како се већ кроз први испис инкорпориран у каталогу заузима дистанца према претходној традицији, те се уместо референце Sermones de sanctis, Biga salutis intitulati (De Lasko 1497) у каталогу на нивоу сажимања као извесног снижавања појављује наслов „Bigua Salutis” (Rabelais 1965: 37; уп. Moreau 1988: 38-39; Bodemer 2012: 4-17). У примерима у којима преводи задржавају исти облик из Раблеовог текста (Rabelais 1965: 37), уз сведенија објашњења, савременом читаоцу можда може и да промакне назначен одјек пародије (уп. Рабле 1973: 181). Такав тон ипак бива наглашенији уколико се донесе одлука да се одређени пример и преведе, те се тако у енглеском преводу референца „Bigua Salutis” из анализираног

\footnotetext{
${ }^{4}$ Термин употребљава Фриц Сен приликом анализе епизоде „Итака” Џојсовог Уликса (Senn 1996: 37).
} 
каталога (Rabelais 1965: 37) наводи као „The two-horse tumbrel of salvation” (Rabelais 1871: 136). Очигледно промишљајући о обе могућности, Станислав Винавер у преводу Раблеовог романа, који је први пут објављен у две књиге 1950. године (Рабле 1950), уз скоро пет страна текста каталога књига, додаје и дуги низ фуснота са коментарима, те се тако за први наведени пример „Bigua Salutis” (Rabelais 1965: 37) у преводу налази: „Bigua Salutis, или Врљика спасенија”, са додатом напоменом уз ову референцу и претходну најаву „списка” (Рабле 1959: 195): „Да би Раблеова пародија на Библиотеку Светога Виктора била јаснија, преводилац је, где је сматрао за потребно, дао најкраћа објашњења. - Уместо Biga Salutis - Двоколице спаса, позната збирка проповеди из 1498. г.” (Винавер у Рабле 1959: 200). Потенцијална дискусија око Винаверовог одабира речи „врљика” у преводу (Рабле 1959: 195) управо би се показала као „eruditna revnost” која каталог и његов превод обележава и као „novi prostor fantastičnog”, под којим се подразумева фукоовски дефинисана невероватност библиотечко-каталошког ,[...] pažljivo[og] sravnjivanj[a] sa izvornikom, mnoštv[a] sićušnih informacija, najmanji[ih] delić[a] spomenikâ i reprodukcij[a] reprodukcijâ [...]" (Fuko 1983: 201-202).

Тумачења претходног примера показују и како се дијалектика каталогенезе књига динамизује у преводима (уп. Ferguson 2019: 230-255). О томе која се све питања у том контексту отварају, сведочи и пример превода каталога референци из једне од фуснота Павићевог романа Хазарски речник (Павић 1996б: 10). Већ на почетку Хазарског речника, у опису његовог „историјата” (Павић 1996б: 9), у првој фусноти нуди се следеће одређење препоручене литературе:

„Преглед литературе о Хазарима објављен је [у] Њујорку (The Khazars, a bibliography, 1939); о историји Хазара у два маха је давао монографије један Рус, М. И. Артамонов (Лењинград 1936. и 1962), а историју јеврејских Хазара публиковао је у Принстону 1954. D. M. Dunlop" (Павић 1996б: 10).

Иако остаје донекле отворена недоумица зашто је одлучено да се име последњег наведеног аутора не транскрибује - „D. M. Dunlop” (Павић 1996б: 10), односно да ли је у питању гест којим се легитимише веродостојност написаног и указује на доступну прилику да се наведена чињеница и провери, ипак се у и назнакама каталога „литературе о Хазарима” у оквирима ове фусноте откривају и неке врсте непрецизности у вези са каталогизацијом поменутих текстова Артамонова (Павић 1996б: 10), које се, на извесне начине, умножавају у преводима. У том смислу се, нпр., у енглеском преводу ове фусноте Хазарског речника назначава да је реч о једној ,[...] монографији о историји Хазара у два издања (Лењинград 1936. и 1962) [...]” (прев. М. Ђ.) „[...] a monograph on the history of the Khazars in two editions (Leningrad, 1936 and 1962) [...]” (Рavić 2017: 11), док се из руског превода ишчитава да „[...] о историји Хазара постоје две монографије руског аутора М. И. Артамонова (Лењинград 1936. и 1962) [...]” (прев. М. Ђ.) - „[...] о истории хазар существуют две монографии русского автора М. И. Артамонова (Ленинград, 1936 и 1962) [...]” (Павич 1991). Истраживањем се утврђује да су у питању публика- 
ције Очерки древнейшей истории хазар (Артамонов 1936) и История хазар (Артамонов 1962), од којих је друга барем три пута развијенија и по обиму и према садржају. Управо би и то могло да се тумачи у фукоовским интерпретацијама Хазарског речника и његових превода као „knjig[e] u kojoj se” и на нивоу референцијалних одређења ,igra fikcija knjiga” и врши непрекидно каталошко преслојавање фантастичног које се налази „u međuprostorima ponavljanjâ i komentarâ; i rađa se i oblikuje u intervalu između dva teksta" (Fuko 1983: 202).

У транслатолошким контекстуализацијама каталога књига, као и у доменима поетичких превредновања која се њима доносе, посебно је занимљив и каталог књига из архитектуре и других блиских дисциплина, уланчан као својеврсни „предах у приповедању” (Пекић 2002: 188) у оквиру Арсенијеве тестаментарне исповести у роману Ходочашће Арсенија Његована Борислава Пекића (Пекић 2002: 189-191). На основу преписке са госпођом Љиљаном Пекић, архитектом, вођене поводом врло богатог каталога књига у овом роману, дошло се и до информација да је при консултацијама коришћених извора значајну улогу имала и библиотека Института за архитектуру и урбанизам у Београду, а да је Борислав Пекић самостално бирао књиге које је одлучио да укључи у списак. ${ }^{5}$ Ако би се имало у виду да би дијалог Арсенија и Исидора у роману могао да се чита не само као полемика у вези са различитим погледима на схватања одређених принципа у архитектури већ и као сучељавање двеју поетичких парадигми у разумевањима доминантних принципа књижевности (уп. Пекић 2002: 292-302), могло би да се постави и питање да ли уланчан каталог књига, донекле попут оног раблезијанског, представља и извесно превредновање неке претходне уметничке парадигме. У том смислу би одговори могли да се наслуте и у оквиру неколиких референци, и то, нпр., аутора пореклом са ових простора, који су нашли своје упориште у контексту каталога који обилује насловима на више страних језика (уп. Пекић 2002: 189-191). Наиме, у каталогу књига у роману Ходочашће Арсенија Његована заступљена је и књига Милутина Борисављевића, париског ученика, коме су били блиски експериментално-психолошки приступи архитектури (уп. Borissavliévitch 1923), у оквиру којих би могао, донекле, да се мотивише и Арсенијев однос према кућама - „8. Dr M. Borisavljević: 'La Science de l'Harmonie architecturale', Paris 1925' (Пекић 2002: 189). Уз то, у оквиру каталога књига који Арсеније Његован намерава да завешта, налази се и дело Бранка Максимовића - „17. Б. Максимовић: ’Урбанизам у Србији - Основна испитивања и документација', Београд 1938." (Пекић 2002: 189), а познато је да је 1967. године, дакле, у периоду очито значајном за Пекићево стваралачко промишљање о лику Арсенија Његована и концепцији романа, Бранко Максимовић публиковао више студија посвећених урбанистичким питањима (уп. Максимовић 1967а; Максимовић 1967б; Максимовић 1967в: 81-98), међу којима се налази и истраживање о Емилијану

\footnotetext{
${ }^{5}$ Преписка са госпођом Љиљаном Пекић вођена је у септембру 2019. године; аутор рада најљубазније захваљује за подељене информације.
} 
Јосимовићу (Максимовић 1967б), аутору чију књигу Арсеније такође поседује у својој библиотеци -,,18. Емилиан Јосимовић: 'Објашњење предлога за регулисање оног дела вароши Београда што лежи у шаниу. Са једним литографисаним планом у размери 1/3000', Београд 1867” (Пекић 2002: 189). Тиме, очигледно, Пекић Арсенијеву наклоност ка рафинираном планирању ситуира у вертикале деловања у сваком од времена врло модерних аутора који проносе европски дух градитељства и чија се остварења у испитиваним годинама (1967/1968) налазе на размеђима другачијих урбанистичких сусрета, што показује да Пекић овим каталогом књига имплицитно нуди и коментар на (не)могућости искушења других архитектонских планирања у односу на она која су дата и Јосимовићевим, а актуелизована Максимовићевим приступима (уп. Mlađenović 1995). Управо се у том смислу и показује на који начин би књиге из архитектуре, урбанизма и других сродних области које се јављају у каталогу у роману Ходочашће Арсенија Његована могле да се тумаче као есенција стваралачко-рецепцијског и полемичког дијалога са претходним парадигмама у уметности, који се даље наставља у кључној расправи о различитом разумевању архитектуре код Арсенија и Исидора (уп. Пекић 2002: 292-302). Иако је, дакле, евидентно да овај каталог књига у Пекићевом роману може да се интерпретира и као референтан списак издања која представљају и неку врсту коментара до тада канонизованих књига у поменутим областима, ипак, у примеру превода књиге Ходошаће Арсенија Његована на енглески језик, услед одабира да се прикаже текст без каталога књига (уп. Рekić 1994: 133), ова врста дијалога остаје недоступна читаоцима енглеског говорног подручја.

Колико су сложену функцију имали извесни каталози књига у библиотекама литерарних јунака, показује и претпоследња епизода Џојсовог Уликса, именована као Одисејева „Итака”, која је конципирана у виду поновног сабирања свега и означена у историји литературе и као „добро каталогизовање” (Leslie 1922: 112-119; Senn 1996: 37). Не би ли се успоставио ред у животу Леополда Блума (Džojs 2008: 692), текст метапоетички наређује каталогизацију „nekoliko naopačke okrenutih knjiga”, међу којима се налази и „Soll und Haben, od Gustava Frajtaga (crni kartonski povez, gotsko pismo, kupon iz kutije cigareta kao obeleživač na str. 24)" (Džojs 2008: 691), која је иначе била „(не)популарна по свом антисловенском и антијеврејском” тону (Mecsnóber 2013: 31). Ова књига са Блумове полице јесте прво издање из 1855 . године, штампано немачком готицом, што означава да ју је Блум наследио од оца, односно да је купљена у Аустрији или Мађарској, а то снажније везује Леополда Блума за централно и источноевропско питање, али и указује на однос назначеног времена и простора према Словенима и другим (мањим или мањинским) народима, што је Џојс индиректно актуелизовао у Улик$c y$, посебно у односу на промену презимена у Блумовој породици и на тематизовање њиховог нестабилног статуса у ксенофобији „Киклопа” Ирске (Mecsnóber 2013: 31-32). Стога се у епизоди „Итака” Џојсовог Уликса, барем и делимичном каталогизацијом књига у приватном простору, настоји да се унесе нека врста повезаности у свету и отвори могућност његовог поновног 
преосмишљавања (Džojs 2008: 692), управо онако како се и жељено „,...] himerično [...] razvija u tišini biblioteke sa kolonama knjiga, sa naslovima poređanim po policama koje je zatvaraju sa svih strana, ali koje se s one strane otvaraju prema svetu nemogućnog" (Fuko 1983: 201).

Кроз претходне примере може да се закључи и да инкорпорирање одређених књига пресудно утиче на разумевање поруке која се каталогом посредује. Каталог, односно мала, привилегована библиотека књига уметника у настајању среће се већ у првим описима Мансарде Данила Киша:

„Pod tim smo zvonom držali ove knjige: Spinozinu Etiku na latinskom, Sveto pismo na hebrejskom, Don Kihota, Marks-Engelsov Manifest, Bretonov Drugi manifest, Priručnik o dijetalnoj ishrani, Misli jednog biologa od Žana Rostana, Jogi za svakog, Džinsovu knjigu o zvezdama, Remboovu Une saison en enfer, Stendalovu knjigu O ljubavi, Vajningerov Pol i karakter, jedno džepno izdanje Van Gogovih reprodukcija i jedan internacionalni red vožnje" (Kiš 2004: 18).

Пре разгранавајуће мреже интертекстуалности, коју каталог као видљиви елемент тока свести постмодерног текста остварује, ова важна библиотека Мансарде евидентира како се уметник у младости односи према књижевној традицији и наслеђу, а посебно на који их начин обликом свога романа мења (уп. Kiš 2004: 18 и даље; Делић 1997: 18-21). Приповедач не дозвољава да се поменуте књиге окрзну, нити да се деконституише њихов текст, већ наизглед анксиозно и гранично модернистички илузорно чува основни међу могућим облицима њиховог резонирања не би ли управо на метатекстуалном нивоу указао колико је облик Мансарде нови антиоблик, различит у односу на све наведене (уп. Кiš 2004; Делић 1997: 18-21). У роману Башта, пепео Киш свој методолошки однос према књигама усложњава не само на нивоу промене облика већ целокупног устројства изабраних књига, о чему сведочи вишестранични списак очеве „литературе” (Киш 2001: 155-157), међу којима су књиге какве су „[...] алхемијске, антрополошке, антропозофске, археолошке, астролошке, астрономске, богословске [...]”, као и оне „[...] версификаторске, волунтаристичке, вулканолошке, зоографске, зоолошке и зоогеографске” (Киш 2001: 155, 157; Ракуза 2005: 169-170), што управо чини и инкарнацију (не)могуће типологије Кишовог романа-пешчаника (Киш 2001: 333-655), као евентуалне „knjige knjigâ” (Fuko 1983: 203).

Инкорпорирање каталога књига у литерарним делима и њиховим преводима очито представља изразито динамизовање дијалектике каталогенезе до граница пуцања смисла каталога, у варијантности начина каталошке (де)стабилизације канона, у припремању поетичке промене и нове форме романа, виђењу каталога као катализатора модернистичког тока свести јунака и обликовања постмодерног тока свести текста, у флоберовском систему упућивања ка „prostoru knjiga” (Fuko 1983: 200-201, 203), за који се у „Енциклопедији мртвих” каже да се „golemom kartotekom” све сређује за „с̌udo biblijskog uskrsnuća”, у коме ће управо лексикографско-енциклопедијски и други каталошки ресурси представити „,velik[u] riznic[u] sećanja i jedinstven dokaz uskrsnuća” (Kiš 1983b: 52), односно начин „da se ispuni rastojanje između 
neba i zemlje" (уп. Eko 2011: 366) управо силом каталогенезе књига, као једном од најевидентнијих тоталитарних моћи живота.

\section{ИЗВОРИ И ЛИТЕРАТУРА}

Артамонов 1936: М. Илларионович Артамонов, Очерки древнейшей истории хазар, Ленинград: Соцэкгиз.

Артамонов 1962: М. Илларионович Артамонов, История хазар, под редакцией и с примечаниями Л. Н. Гумилёва, Ленинград: Изд-во Гос. Эрмитажа.

Делић 1997: Ј. Делић, Кроз прозу Данила Киша: ка поетищи Кишове прозе, књ. 2, Београд: БИГЗ.

Златковић 1997: И. Златковић, „Покушај теоријског одређења каталога јунака у Вишњићевим устаничким песмама”, у: Ненад Љубинковић, прир., Карађорђеве војводе у историји, епу и драми: зборник радова са научног скупа и поводом юега, Београд: Институт за књижевност и уметност; Велика Плана: Скупштина општине, 117-126.

Киш 2001: Д. Киш, Породични циркус: Рани јади, Башта, пепео, Пешчаник, Београд: Просвета.

Максимовић 1967а: Б. Максимовић, Ка методу раџионализовања композиичје стамбеног комплекса, Београд: „Научно дело”.

Максимовић 1967б: Б. Максимовић, Емилијан Јосимовић: први српски урбанист, Београд: Институт за архитектуру и урбанизам Србије.

Максимовић 1967в: Б. Максимовић, „Естетичка схватања композиције градских центара Београда почетком 20. века", Годишьак града Београда, књ. 14, 1967, 81-98.

Матицки 1997: М. Матицки, „Удео каталога Карађорђевих војвода у легенди о устанку", у: Ненад Љубинковић, прир., Карађорђеве војводе у историји, епу и драми: зборник радова са научног скупа и поводом њега, Београд: Институт за књижевност и уметност; Велика Плана: Скупштина општине, 109-116.

Павић 1996а: М. Павић, Предео сликан чајем: роман за љубитеље укритених речи, Сабрана дела Милорада Павића у 10 књига, књига 6, приредили Јасмина Михајловић, Александар Јерков, Београд: „Драганић”.

Павић 1996б: М. Павић, Хазарски речник, Сабрана дела Милорада Павића у 10 къига, књига 5, приредили Јасмина Михајловић, Александар Јерков, Београд: „Драганић”.

Павич 1991: М. Павич, „Хазарский словарь: Роман-лексикон в 100000 слов (Фрагменты)", перевод Ларисы Савельевой, Иностранная литература, 3: https://www.rastko.rs/knjizevnost/pavic/ruski/hazar.htm; приступљено последњи пут 4. 10. 2019. 
Пекић 2002: Б. Пекић, Ходочашће Арсенија Његована, приредио и предговор написао Радивоје Микић, Београд: Завод за уџбенике и наставна средства.

Петровић 2013: П. Петровић, Откриване тоталитета: романи Ра-стка Петровића, Београд: Службени гласник.

Петровић 2014: Р. Петровић, Дан шести, Београд: Плато.

Рабле 1950: Ф. Рабле, Гаргантуа и Пантагруел, у 2 књиге, превео с француског Станислав Винавер, предговор написао Ели Финци, Београд: Просвета.

Рабле 1959: Ф. Рабле, Гаргантуа и Пантагруел, друго издање, превео с француског Станислав Винавер, предговор написао Ели Финци, Београд: Просвета.

Рабле 1973: Ф. Рабле, Гаргантюа и Пантагрюэль, перевод с французского Николая Любимова, Москва: Издательство „Художественная литература”.

Ракуза 2005: И. Ракуза, „Књижевни инвентари Данила Киша”, превео с немачког Златко Красни, у: Предраг Палавестра, ур., Споменица Данила Киша: поводом седамдесетогодишњище рођења, Београд: Српска академија наука и уметности, 165-174.

Самарџија 2013: С. Самарџија, „Функције каталога у лирској народној поезији", 42. научни састанак слависта у Вукове дане, Развојни токови српске поезије, том 1, 25-38.

Сувајџић 2010: Б. Сувајџић, Певач и традиција, Београд: Завод за уџбенике. Хомер 2002а: Хомер, Одисеја, превео Милош Ђурић, Београд: Завод за уџбенике и наставна средства.

Хомер 2002б: Хомер, Илијада, превео Милош Ђурић, приредио Војислав Јелић, пропратне текстове написао Мирон Флашар, Београд: Завод за уџбенике и наставна средства.

Besson 1980: A. Besson, Medieval Classification \& Cataloguing: Classification Practices and Cataloguing Methods in France from the $12^{\text {th }}$ to $15^{\text {th }}$ Centuries, Biggleswade, Beds.: Clover Publications.

Bodemer 2012: B. Bodemer, „Rabelais and the Abbey of Saint-Victor Revi-sited”, Information \& Culture, Volume 47, Issue 1, January 2012, 4-17.

Borissavliévitch 1923: M. Borissavliévitch, „Découverte de la perspective opticophysiologique", Bulletin de l'École Spéciale d'architecture, no 3, août 1923, $13-16$.

Bošković 2004: D. Bošković, Islednik, svedok, priča: istražni postupci u Peščaniku i Grobnici za Borisa Davidoviča Danila Kiša, Beograd: Plato.

De Lasko 1497: O. de Lasko, Sermones de sanctis, Biga salutis intitulati, Hagenau: Heinrich Gran, pro Johannes Rynman.

Džojs 2008: Dž. Džojs, Uliks, prevod, komentari i pogovor Zoran Paunović, Beograd: Geopoetika.

Eko 2011: U. Eko, Beskrajni spiskovi, s italijanskog preveo Aleksandar V. Stefanović, Beograd: Plato. 
Ferguson 2019: R. Ferguson, „Sir Thomas Urquhart's Translation (1653) of Rabelais's Imaginary Library of St. Victor (1542)", in: Anne-Pascale Pouey-Mounou, Paul J. Smith, eds., Early Modern Catalogues of Imaginary Books: A Scholarly Anthology, Leiden, Boston: Brill, 230-255.

Foucault 1967: M. Foucault, „Un 'fantastique' de bibliothèque”, Cahiers de la compagnie Madeleine Renaud et Jean-Louis Barrault, no 59, mars 1967, 7-30.

Fuko 1983: M. Fuko, „'Fantastika' biblioteke”, u: Danilo Kiš, Čas anatomije, Zagreb: Globus; Beograd: Prosveta, 200-203.

Gray 2012: V. J. Gray, „Herodotus on Melampus”, in: Emily Baragwanath, Mathieu de Bakker, eds., Myth, Truth, and Narrative in Herodotus, Oxford: Oxford University Press, 167-191.

Homer 1919: H., The Odyssey, with an English translation by A.T. Murray, in two volumes, Cambridge, MA.: Harvard University Press; London: William Heinemann, Ltd., Od. - коришћена скраћеница у тексту.

Joyce 1975: J. Joyce, Finnegans Wake, London: Faber and Faber, FW - коришћена скраћеница у тексту.

Joyce 1986: J. Joyce, Ulysses, Gabler Edition, New York: Vintage Books/Random House, $U$ - коришћена скраћеница у тексту.

Kiš 1983a: D. Kiš, Homo poeticus, Zagreb: Globus; Beograd: Prosveta.

Kiš 1983b: D. Kiš, Enciklopedija mrtvih, Zagreb: Globus; Beograd: Prosveta.

Kiš 2004: D. Kiš, Mansarda: satirična poema, Sabrana dela Danila Kiša, knjiga prva, u redakciji Mirjane Miočinović, Beograd: Prosveta.

Leslie 1922: S. Leslie, „Ulysses”, Dublin Review, CLXXI, September 1922, 112-119.

Lotman 1976: J. Mihajlovič Lotman, Struktura umetničkog teksta, prevod i predgovor Novica Petković, Beograd: Nolit.

Mecsnóber 2013: T. Mecsnóber, „James Joyce and 'Eastern Europe': An Introduction", in: R. Brandon Kershner, Tekla Mecsnóber, eds., Joycean Unions: Post-Millennial Essays from East to West, European Joyce Studies, Vol. 22, Amsterdam and New York: Rodopi, 15-45.

Mlađenović 1995: I. Mlađenović, „Modern Serbian Architecture”, in: Pavle Ivić, ed., The History of Serbian Culture, translated by Randall A. Major, Edgware: Porthill.

Moreau 1988: F. Moreau, „La bibliothèque de Saint-Victor (Pantagruel, chapitre VII)", Littératures, 19, automne 1988, 37-42.

Pavić 2017: M. Pavić, Dictionary of the Khazars: A Lexicon Novel in 100.000 Words, The Androgynous Edition, translated by Kristina Pribićević-Zorić, Belgrade: Dereta.

Pekić 1994: B. Pekić, The Houses of Belgrade, translated by Bernard Johnson, Evanston: Northwestern University Press.

Pekić 2012: B. Pekić, Zlatno runo II, Beograd: Laguna.

Perišić 2013: I. Perišić, Utopija smeha: vidovi komike i smeha u romanima Mrtve duše Nikolaja Gogolja, Uliks Džejmsa Džojsa i Zlatno runo Borislava Pekića, Beograd: Službeni glasnik. 
Rabelais 1884: F. Rabelais, The Works of Rabelais, faithfully translated from the French with variorum notes, and numerous illustrations by Gustave Doré, London: Chatto \& Windus.

Rabelais 1965: F. Rabelais, Pantagruel, nouvelle édition augmentée, première publication critique sur le texte original par V. L. Saulnier, Genève: Librairie Droz.

Screech 1979: M. A. Screech, Rabelais, Ithaca: Cornell University Press.

Senn 1996: F. Senn, ,'Ithaca': Portrait of the Chapter as a Long List”, in: Andrew Gibson, ed., Joyce's „Ithaca”, European Joyce Studies, Vol. 6, Amsterdam and Atlanta, GA: Rodopi, 31-76.

Taylor 1961: J. Taylor, The Didascalicon of Hugh of St. Victor, New York: Columbia University Press.

Mina M. Đurić

\section{CATALOGOGENESIS OF BOOKS IN (POST)MODERN PROSE}

(Summary)

The paper examines various aspects of book catalogues in (post)modern prose of Serbian and world literature. The research analyses the poetics of the book catalogue in the domains of lexicographical and encyclopaedic paradigm. If the catalogue of the books in the text is a narrative break, if it should be translated or not, if it is a sign of a new poetical paradigm are some of the main questions interpreted through Foucault's ideas of fantasia of the library (Foucault 1967: 7-30). 